\title{
Kinetics and Mechanism of the Anilinolysis of Dibutyl Chlorophosphate in Acetonitrile
}

\author{
Md. Ehtesham Ul Hoque and Hai Whang Lee* \\ Department of Chemistry, Inha University, Incheon 402-751, Korea. ${ }^{*}$ E-mail: hwlee@inha.ac.kr \\ Received November 14, 2011, Accepted December 2, 2011
}

\begin{abstract}
The nucleophilic substitution reactions of dibutyl chlorophosphate (3) with substituted anilines $\left(\mathrm{XC}_{6} \mathrm{H}_{4} \mathrm{NH}_{2}\right)$ and deuterated anilines $\left(\mathrm{XC}_{6} \mathrm{H}_{4} \mathrm{ND}_{2}\right)$ are investigated kinetically in acetonitrile at $55.0^{\circ} \mathrm{C}$. The obtained deuterium kinetic isotope effects (DKIEs; $\left.k_{\mathrm{H}} / k_{\mathrm{D}}\right)$ are secondary inverse $\left(k_{\mathrm{H}} / k_{\mathrm{D}}=0.86-0.97\right)$ with the strongly basic anilines while primary normal $\left(k_{\mathrm{H}} / k_{\mathrm{D}}=1.04-1.10\right)$ with the weakly basic anilines. The DKIEs, steric effects of the two ligands, activation parameters, cross-interaction constants, variation trends of the $k_{\mathrm{H}} / k_{\mathrm{D}}$ values with $X$, and mechanism are discussed for the anilinolyses of the nine $\left(\mathrm{R}_{1} \mathrm{O}\right)\left(\mathrm{R}_{2} \mathrm{O}\right) \mathrm{P}(=\mathrm{O}) \mathrm{Cl}$-type chlorophosphates. A concerted mechanism is proposed with a backside nucleophilic attack transition state for the strongly basic anilines and with a frontside attack involving a hydrogen-bonded four-center-type transition state for the weakly basic anilines on the basis of the magnitudes, secondary inverse and primary normal, and variation trends of the $k_{\mathrm{H}} / k_{\mathrm{D}}$ values with $\mathrm{X}$.
\end{abstract}

Key Words : Phosphoryl transfer reaction, Anilinolysis, Dibutyl chlorophosphate, Deuterium kinetic isotope effect

\section{Introduction}

Phosphoryl and thiophosphoryl transfer reactions have been studied extensively and a considerable amount of work has been carried out to clarify the mechanism. Two main types of mechanisms, the stepwise mechanism involving a trigonal bipyramidal pentacoordinate (TBP-5C) intermediate and the concerted mechanism through a single pentacoordinate transition state (TS), are known to occur in neutral phosphoryl and thiophosphoryl transfer reactions. The experimental (aminolysis: anilinolysis, ${ }^{1}$ pyridinolysis, ${ }^{2}$ and benzylaminolysis ${ }^{3}$ ) and theoretical ${ }^{4}$ studies on the phosphoryl and thiophosphoryl transfer reactions of various substrates have been carried out extensively by this lab. In the present work, the nucleophilic substitution reactions of dibutyl chlorophosphate (3) with substituted anilines $\left(\mathrm{XC}_{6} \mathrm{H}_{4} \mathrm{NH}_{2}\right)$ and deuterated anilines $\left(\mathrm{XC}_{6} \mathrm{H}_{4} \mathrm{ND}_{2}\right)$ are investigated kinetically in acetonitrile $(\mathrm{MeCN})$ at $55.0 \pm$ $0.1{ }^{\circ} \mathrm{C}$ (Scheme 1). The aim of this work is to gain further systematic information into the phosphoryl transfer reaction mechanisms, as well as to compare with the deuterium kinetic isotope effects (DKIEs; $k_{\mathrm{H}} / k_{\mathrm{D}}$ ) on the relevant anilinolyses of $\left(\mathrm{R}_{1} \mathrm{O}\right)\left(\mathrm{R}_{2} \mathrm{O}\right) \mathrm{P}(=\mathrm{O}) \mathrm{Cl}$-type chlorophosphates where $\mathrm{R}_{1}$ and $\mathrm{R}_{2}$ are alkyl and/or phenyl (aryl): dimethyl [1: $\left.(\mathrm{MeO})_{2} \mathrm{P}(=\mathrm{O}) \mathrm{Cl}\right],{ }^{1 \mathrm{~g}}$ diethyl $\left[2:(\mathrm{EtO})_{2} \mathrm{P}(=\mathrm{O}) \mathrm{Cl}\right],{ }^{1 \mathrm{~g}}$ diisopropyl [4: $\left.(i-\mathrm{PrO})_{2} \mathrm{P}(=\mathrm{O}) \mathrm{Cl}\right],{ }^{1 \mathrm{r}} \mathrm{Y}$-aryl ethyl [5: $(\mathrm{EtO})\left(\mathrm{YC}_{6} \mathrm{H}_{4} \mathrm{O}\right)-$ $\mathrm{P}(=\mathrm{O}) \mathrm{Cl}],{ }^{1 \mathrm{f}} \mathrm{Y}$-aryl phenyl [6: $\left.(\mathrm{PhO})\left(\mathrm{YC}_{6} \mathrm{H}_{4} \mathrm{O}\right) \mathrm{P}(=\mathrm{O}) \mathrm{Cl}\right]{ }^{1 \mathrm{a}}$ Y-aryl 4-chlorophenyl [7: $\left.\left(4-\mathrm{Cl}-\mathrm{C}_{6} \mathrm{H}_{4} \mathrm{O}\right)\left(\mathrm{YC}_{6} \mathrm{H}_{4} \mathrm{O}\right) \mathrm{P}(=\mathrm{O}) \mathrm{Cl}\right]{ }^{1 \mathrm{~b}}$ and bis(Y-aryl) [8: $\left.\left(\mathrm{YC}_{6} \mathrm{H}_{4} \mathrm{O}\right)_{2} \mathrm{P}(=\mathrm{O}) \mathrm{Cl}\right]^{1 \mathrm{n}}$ chlorophosphates in $\mathrm{MeCN}$, and bis(2,6-dimethylphenyl) chlorophosphate [9: $\left.\left(2,6-\mathrm{Me}_{2} \mathrm{C}_{6} \mathrm{H}_{3} \mathrm{O}\right)_{2} \mathrm{P}(=\mathrm{O}) \mathrm{Cl}\right]^{1 \mathrm{t}}$ in dimethyl sulfoxide (DMSO). The numbering of the substrates of 1-9 follows the sequence of the summation of the Taft's steric constants of the two ligands, $R_{1}$ and $R_{2}$. The relative reactivities of the substrates

$$
\begin{gathered}
\overbrace{\mathrm{BuO}} \\
\mathrm{X}=4-\mathrm{MeO}, 4-\mathrm{Me}, 3-\mathrm{Me}, \mathrm{H}, 3-\mathrm{MeO}, 4-\mathrm{Cl}, 3-\mathrm{Cl}
\end{gathered}
$$

Scheme 1. The anilinolysis of dibutyl chlorophosphate (3) in $\mathrm{MeCN}$ at $55.0^{\circ} \mathrm{C}$.

are discussed on the basis of the magnitude of the positive charge of the reaction center phosphorus atom and steric effects of the two ligands $\left(\mathrm{R}_{1} \mathrm{O}\right.$ and $\left.\mathrm{R}_{2} \mathrm{O}\right)$ in the substrate. The substituent $(\mathrm{X})$ effects on the DKIEs are discussed on the basis of the variation trends of the magnitudes of the $k_{\mathrm{H}} /$ $k_{\mathrm{D}}$ values with $\mathrm{X}$ depending upon the primary normal and secondary normal DKIEs. The variation trends of the $k_{\mathrm{H}} / k_{\mathrm{D}}$ values with $\mathrm{X}$ are correlated with the mechanism: concerted and stepwise.

The B3LYP/6-311+G(d,p) geometry, bond angles, and natural bond order (NBO) charges of $\mathbf{3}$ in the gas phase ${ }^{5}$ are shown in Figure 1. The MO theoretical structure shows that the three oxygens and chlorine have somewhat distorted

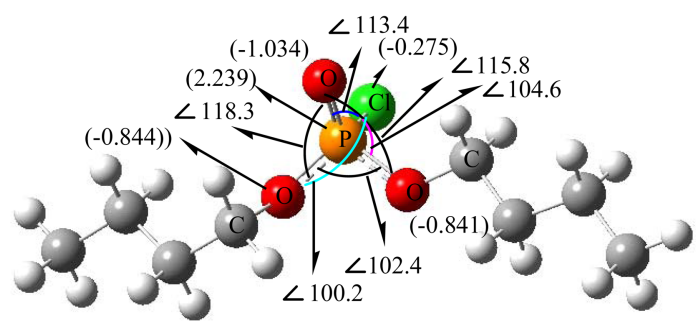

Figure 1. The B3LYP/6-311+G(d,p) geometry of dibutyl chlorophosphate (3) in the gas phase. 
tetrahedral geometry with the phosphorus atom at the center. The ground sate (GS) structure of $\mathbf{3}$ does not have symmetry plane although it has the two same ligands of $\mathrm{BuO}$, giving the difference in the negative charges of the two butoxy oxygens.

\section{Results and Discussion}

The observed pseudo-first-order rate constants $\left(k_{\mathrm{obsd}}\right)$ were found to follow eq. (1) for all the reactions under pseudofirst-order conditions with a large excess of aniline nucleophile. The $k_{0}$ values were negligible $\left(k_{0} \approx 0\right)$ in $\mathrm{MeCN}$. The clean second-order rate constants $\left(k_{\mathrm{H}(\mathrm{D})}\right)$ were determined as the slope of the plot of $k_{\text {obsd }}$ against at least five concentrations of anilines. The linear plots of eq. (1) suggest that there is no base-catalysis or noticeable side reaction and that the overall reaction is described by Scheme 1 .

$$
k_{\mathrm{obsd}}=k_{0}+k_{\mathrm{H}(\mathrm{D})}\left[\mathrm{XC}_{6} \mathrm{H}_{4} \mathrm{NH}_{2}\left(\mathrm{D}_{2}\right)\right]
$$

The $k_{\mathrm{H}}$ and $k_{\mathrm{D}}$ values are summarized in Table 1, together with the DKIEs $\left(k_{\mathrm{H}} / k_{\mathrm{D}}\right)$ and the Hammett $\rho_{\mathrm{X}}$ and Brönsted $\beta_{\mathrm{X}}$ selectivity parameters. The $\mathrm{p} K_{\mathrm{a}}(\mathrm{X})$ values of the $\mathrm{X}$ anilines in water were used to obtain the Brönsted $\beta_{\mathrm{X}}$ values in $\mathrm{MeCN}$, and this procedure was justified experimentally and theoretically. ${ }^{6}$ The values of $\mathrm{p} K_{\mathrm{a}}(\mathrm{X})$ and $\sigma_{\mathrm{X}}$ of the deuterated $\mathrm{X}$-anilines are assumed to be identical to those of the X-anilines. Perrin and coworkers reported that the basicities of $\beta$-deuterated analogs of benzylamine, $\mathrm{N}, \mathrm{N}$ dimethylaniline and methylamine increase roughly by 0.02 $\mathrm{p} K_{\mathrm{a}}$ units per deuterium, and that these effects are additive. ${ }^{7}$ Thus, the $\mathrm{p} K_{\mathrm{a}}(\mathrm{X})$ values of deuterated $\mathrm{X}$-anilines may be slightly greater than those of $\mathrm{X}$-anilines, however, the difference is too small to be taken into account. Figures 2 and 3 show the Hammett $\left(\log k_{\mathrm{H}(\mathrm{D})} v s \sigma_{\mathrm{X}}\right)$ and Brönsted [log $k_{\mathrm{H}(\mathrm{D})} v s \mathrm{p} K_{\mathrm{a}}(\mathrm{X})$ ] plots, respectively, for substituent $\mathrm{X}$ variations in the nucleophiles. The stronger nucleophile leads to the faster rate as observed in a typical nucleophilic substitution reaction with positive charge development at the

Table 1. The Second-Order Rate Constants $\left(k_{\mathrm{H}(\mathrm{D})} \times 10^{3} / \mathrm{M}^{-1} \mathrm{~s}^{-1}\right)$, Selectivity Parameters $\left(\rho_{\mathrm{X}}\right.$ and $\left.\beta_{\mathrm{X}}\right),{ }^{a}$ and DKIEs $\left(k_{\mathrm{H}} / k_{\mathrm{D}}\right)$ of the Reactions of Dibutyl Chlorophosphate (3) with $\mathrm{XC}_{6} \mathrm{H}_{4} \mathrm{NH}_{2}\left(\mathrm{D}_{2}\right)$ in $\mathrm{MeCN}$ at $55.0^{\circ} \mathrm{C}$

\begin{tabular}{cccc}
\hline $\mathrm{X}$ & $k_{\mathrm{H}} \times 10^{3}$ & $k_{\mathrm{D}} \times 10^{3}$ & $k_{\mathrm{H}} / k_{\mathrm{D}}$ \\
\hline $4-\mathrm{MeO}$ & $16.0 \pm 0.1^{b}$ & $16.5 \pm 0.1$ & $0.970 \pm 0.008^{g}$ \\
$4-\mathrm{Me}$ & $7.16 \pm 0.03$ & $7.66 \pm 0.03$ & $0.935 \pm 0.005$ \\
$3-\mathrm{Me}$ & $3.12 \pm 0.01$ & $3.48 \pm 0.01$ & $0.897 \pm 0.004$ \\
$\mathrm{H}$ & $2.06 \pm 0.01$ & $2.40 \pm 0.01$ & $0.858 \pm 0.005$ \\
$3-\mathrm{MeO}$ & $0.866 \pm 0.001$ & $0.830 \pm 0.003$ & $1.04 \pm 0.01$ \\
$4-\mathrm{Cl}$ & $0.400 \pm 0.001$ & $0.376 \pm 0.001$ & $1.06 \pm 0.01$ \\
$3-\mathrm{Cl}$ & $0.152 \pm 0.001$ & $0.138 \pm 0.001$ & $1.10 \pm 0.01$ \\
$-\rho_{\mathrm{X}}$ & $3.13 \pm 0.03^{c}$ & $3.26 \pm 0.03^{e}$ & \\
$\beta_{\mathrm{X}}$ & $1.11 \pm 0.04^{d}$ & $1.15 \pm 0.05^{f}$ & \\
\hline
\end{tabular}

${ }^{a}$ The $\sigma$ values were taken from ref. 8. The $\mathrm{p} K_{\mathrm{a}}$ values of $\mathrm{X}$-anilines in water were taken from ref. 9. ${ }^{b}$ Standard deviation. ${ }^{c}$ Correlation coefficient, $\mathrm{r}=0.999 .{ }_{\mathrm{r}}=0.999 .{ }^{e_{\mathrm{r}}}=0.999 .{ }_{\mathrm{r}}=0.998 .{ }^{g}$ Standard error $\{=1 /$ $\left.k_{\mathrm{D}}\left[\left(\Delta k_{\mathrm{H}}\right)^{2}+\left(k_{\mathrm{H}} / k_{\mathrm{D}}\right)^{2} \times\left(\Delta k_{\mathrm{D}}\right)^{2}\right]^{1 / 2}\right\}$ from ref. 10.

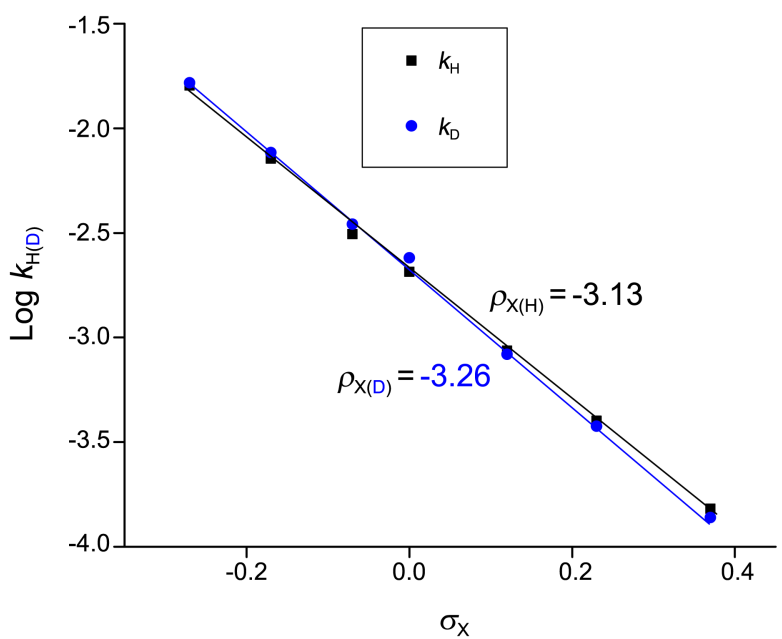

Figure 2. The Hammett plots $\left(\log k_{\mathrm{H}(\mathrm{D})} v s \sigma_{\mathrm{X}}\right)$ of the reactions of dibutyl chlorophosphate (3) with $\mathrm{XC}_{6} \mathrm{H}_{4} \mathrm{NH}_{2}\left(\mathrm{D}_{2}\right)$ in $\mathrm{MeCN}$ at 55.0 ${ }^{\circ} \mathrm{C}$.

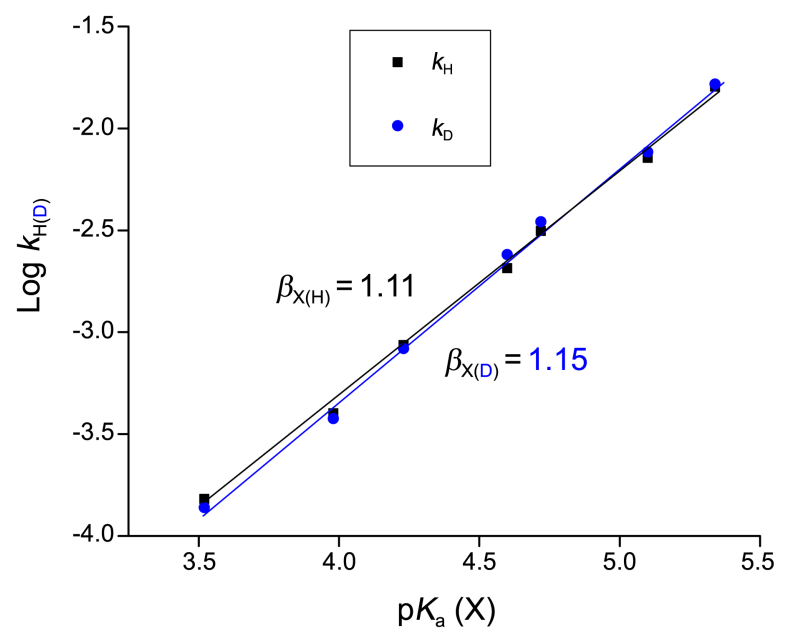

Figure 3. The Brönsted plots $\left[\log k_{\mathrm{H}(\mathrm{D})} v s \mathrm{p} K_{\mathrm{a}}(\mathrm{X})\right]$ of the reactions of dibutyl chlorophosphate (3) with $\mathrm{XC}_{6} \mathrm{H}_{4} \mathrm{NH}_{2}\left(\mathrm{D}_{2}\right)$ in $\mathrm{MeCN}$ at $55.0{ }^{\circ} \mathrm{C}$.

nucleophilic $\mathrm{N}$ atom in the TS. The DKIEs are secondary inverse $\left(k_{\mathrm{H}} / k_{\mathrm{D}}<1\right)$ with more basic anilines $(\mathrm{X}=4-\mathrm{MeO}, 4-$ $\mathrm{Me}$, 3-Me, and $\mathrm{H})$ while primary normal $\left(k_{\mathrm{H}} / k_{\mathrm{D}}>1\right)$ with less basic anilines $(\mathrm{X}=3-\mathrm{MeO}, 4-\mathrm{Cl}$, and $3-\mathrm{Cl})$. The values of DKIEs invariably decrease, via $\mathrm{X}=\mathrm{H}\left(k_{\mathrm{H}} / k_{\mathrm{D}}=0.86\right.$; minimum value), and then invariably increase as the aniline becomes less basic. The magnitudes of $\rho_{\mathrm{X}}$ and $\beta_{\mathrm{X}}$ values with deuterated anilines are somewhat greater than those with anilines, suggesting more sensitive to substituent $\mathrm{X}$ effect of deuterated anilines compared to that of anilines.

The second-order rate constants $\left(k_{\mathrm{H}}\right)$ with unsubstituted aniline $\left(\mathrm{C}_{6} \mathrm{H}_{5} \mathrm{NH}_{2}\right)$ at $55.0{ }^{\circ} \mathrm{C}, \mathrm{NBO}$ charges at the reaction center $\mathrm{P}$ atom [B3LYP/6-311+G(d,p) level of theory] in the gas phase, ${ }^{5}$ summations of the Taft's steric constants of $\mathrm{R}_{1}$ and $\mathrm{R}_{2}\left[\Sigma E_{\mathrm{S}}=E_{\mathrm{S}}\left(\mathrm{R}_{1}\right)+E_{\mathrm{S}}\left(\mathrm{R}_{2}\right)\right],{ }^{11}$ Brönsted coefficients $\left(\beta_{\mathrm{X}(\mathrm{H})}\right.$ and $\left.\beta_{\mathrm{X}(\mathrm{D})}\right)$, DKIEs $\left(k_{\mathrm{H}} / k_{\mathrm{D}}\right)$, the variation trends of DKIEs with substituent $\mathrm{X}$ in the nucleophiles, and cross-interaction constants $\left(\mathrm{CICs} ; \rho_{\mathrm{XY}}\right)^{12}$ of the reactions of $\mathbf{1 - 9}$ with $\mathrm{XC}_{6} \mathrm{H}_{4} \mathrm{NH}_{2}\left(\mathrm{D}_{2}\right)$ are summarized in Table 2. The employed 
Table 2. Summary of the Second-Order Rate Constants $\left(k_{\mathrm{H}} \times 10^{3} / \mathrm{M}^{-1} \mathrm{~s}^{-1}\right)$ with $\mathrm{C}_{6} \mathrm{H}_{5} \mathrm{NH}_{2}$ at $55.0^{\circ} \mathrm{C}$, NBO Charges at the Reaction Center $\mathrm{P}$ Atom, Summations of the Taft's Steric Constants of $\mathrm{R}_{1}$ and $\mathrm{R}_{2}\left[\Sigma E_{\mathrm{S}}=E_{\mathrm{S}}\left(\mathrm{R}_{1}\right)+E_{\mathrm{S}}\left(\mathrm{R}_{2}\right)\right]$, Brönsted Coefficients $\left(\beta_{\mathrm{X}(\mathrm{H})}\right)$, DKIEs $\left(k_{\mathrm{H}} / k_{\mathrm{D}}\right)$, Variation Trends of $k_{\mathrm{H}} / k_{\mathrm{D}}$ with X, and CICs $\left(\rho_{\mathrm{XY}}\right)$ for the Reactions of 1-9 with $\mathrm{XC}_{6} \mathrm{H}_{4} \mathrm{NH}_{2}\left(\mathrm{D}_{2}\right)$

\begin{tabular}{|c|c|c|c|c|c|c|c|}
\hline Substrate & $k_{\mathrm{H}} \times 10^{3 a}$ & Charge at $P$ & $-\Sigma E_{\mathrm{S}}{ }^{b}$ & $\beta_{\mathrm{X}(\mathrm{H})}$ & $k_{\mathrm{H}} / k_{\mathrm{D}}$ & Trend & $\rho_{\mathrm{XY}}$ \\
\hline 1: $(\mathrm{MeO})_{2} \mathrm{P}(=\mathrm{O}) \mathrm{Cl}$ & 4.28 & 2.226 & 0.00 & 0.96 & $0.80-0.98$ & $\uparrow$ & - \\
\hline 2: $(\mathrm{EtO})_{2} \mathrm{P}(=\mathrm{O}) \mathrm{Cl}$ & 2.82 & 2.236 & 0.14 & 1.06 & $0.71-0.92$ & $\uparrow$ & - \\
\hline 3: $(\mathrm{BuO})_{2} \mathrm{P}(=\mathrm{O}) \mathrm{Cl}$ & 2.06 & 2.239 & 0.78 & 1.11 & $0.86-1.10$ & $\uparrow+\downarrow$ & - \\
\hline 4: $(i-\mathrm{PrO})_{2} \mathrm{P}(=\mathrm{O}) \mathrm{Cl}$ & 0.710 & 2.269 & 0.94 & 1.10 & $0.71-0.95$ & $\downarrow+\uparrow$ & - \\
\hline 5: $(\mathrm{EtO})\left(\mathrm{YC}_{6} \mathrm{H}_{4} \mathrm{O}\right) \mathrm{P}(=\mathrm{O}) \mathrm{Cl}$ & 2.00 & 2.233 & 2.55 & 1.13 & $1.07-1.28$ & $\downarrow$ & -0.60 \\
\hline 6: $(\mathrm{PhO})\left(\mathrm{YC}_{6} \mathrm{H}_{4} \mathrm{O}\right) \mathrm{P}(=\mathrm{O}) \mathrm{Cl}$ & 0.891 & 2.230 & 4.96 & $1.24-1.68$ & $0.61-0.87$ & $\uparrow$ & -1.31 \\
\hline 7: $\left(4-\mathrm{Cl}-\mathrm{C}_{6} \mathrm{H}_{4} \mathrm{O}\right)\left(\mathrm{YC}_{6} \mathrm{H}_{4} \mathrm{O}\right) \mathrm{P}(=\mathrm{O}) \mathrm{Cl}$ & 1.20 & 2.229 & $>4.96$ & $1.43-1.49$ & $0.64-0.87$ & $\uparrow$ & -0.31 \\
\hline 8: $\left(\mathrm{YC}_{6} \mathrm{H}_{4} \mathrm{O}\right)_{2} \mathrm{P}(=\mathrm{O}) \mathrm{Cl}$ & 0.891 & 2.230 & 4.96 & $1.29-1.56$ & $0.55-0.98$ & $\downarrow$ & +1.91 \\
\hline 9: $\left(2,6-\mathrm{Me}_{2} \mathrm{C}_{6} \mathrm{H}_{3} \mathrm{O}\right)_{2} \mathrm{P}(=\mathrm{O}) \mathrm{Cl}$ & $5.98^{c}$ & 2.214 & $>4.96$ & 0.29 & $0.87-0.92$ & $\downarrow$ & - \\
\hline
\end{tabular}

${ }^{a}$ The values with unsubstituted aniline at $55.0^{\circ} \mathrm{C}$. The second-order rate constant of $\mathbf{9}$ is the value in DMSO, while those of 1-8 are the values in MeCN. ${ }^{b}$ Note that the value of $\Sigma E_{\mathrm{S}}$ is not $E_{\mathrm{S}}\left(\mathrm{R}_{1} \mathrm{O}\right)+E_{\mathrm{S}}\left(\mathrm{R}_{2} \mathrm{O}\right)$ but $E_{\mathrm{S}}\left(\mathrm{R}_{1}\right)+E_{\mathrm{S}}\left(\mathrm{R}_{2}\right)$ since the data of Taft's steric constants of $\mathrm{R}_{\mathrm{i}} \mathrm{O}$ are not available.

solvents are MeCN and DMSO for 1-8 and 9, respectively. The variation trends of the $k_{\mathrm{H}} / k_{\mathrm{D}}$ values with $\mathrm{X}$ are represented as symbol of arrow. The vertical arrow of $\uparrow$ indicates that the $k_{\mathrm{H}} / k_{\mathrm{D}}$ value increases with a stronger nucleophile, while the vertical arrow of $\downarrow$ indicates that the $k_{\mathrm{H}} / k_{\mathrm{D}}$ value increases with a weaker nucleophile. The symbol of $\uparrow+\downarrow$ indicates that the $k_{\mathrm{H}} / k_{\mathrm{D}}$ value invariably decreases, via minimum value, and then invariably increases as the aniline becomes less basic. On the other hand, the symbol of $\downarrow+\uparrow$ indicates that the $k_{\mathrm{H}} / k_{\mathrm{D}}$ value invariably increases, via maximum value, and then invariably decreases as the aniline becomes less basic. The Brönsted coefficients $\left(\beta_{\mathrm{X}(\mathrm{H})}\right)$ are in the range of $0.96-1.68$, when excluding 9. The $\beta_{\mathrm{X}(\mathrm{H})}$ values invariably increase as the size of the two ligands becomes greater for 1-6. There are no systematic correlations between: (i) $\beta_{\mathrm{X}(\mathrm{H})}$ and $k_{\mathrm{H}} / k_{\mathrm{D}}$ values; (ii) $\beta_{\mathrm{X}(\mathrm{H})}$ values and variation trends of $k_{\mathrm{H}} / k_{\mathrm{D}}$; and (iii) $k_{\mathrm{H}} / k_{\mathrm{D}}$ values and variation trends of $k_{\mathrm{H}} / k_{\mathrm{D}}$

There is no correlation between the second-order rate constant and positive charge at the reaction center $\mathrm{P}$ atom, implying that the inductive effects of the two ligands do not play any role to decide the reactivity of anilinolysis of $\left(\mathrm{R}_{1} \mathrm{O}\right)\left(\mathrm{R}_{2} \mathrm{O}\right) \mathrm{P}(=\mathrm{O}) \mathrm{Cl}$-type substrates. Nevertheless, the rate of 6 is 1.3 times faster than that of 7, due to the additional electron-withdrawing substituent of 4-chloro in the substrate.

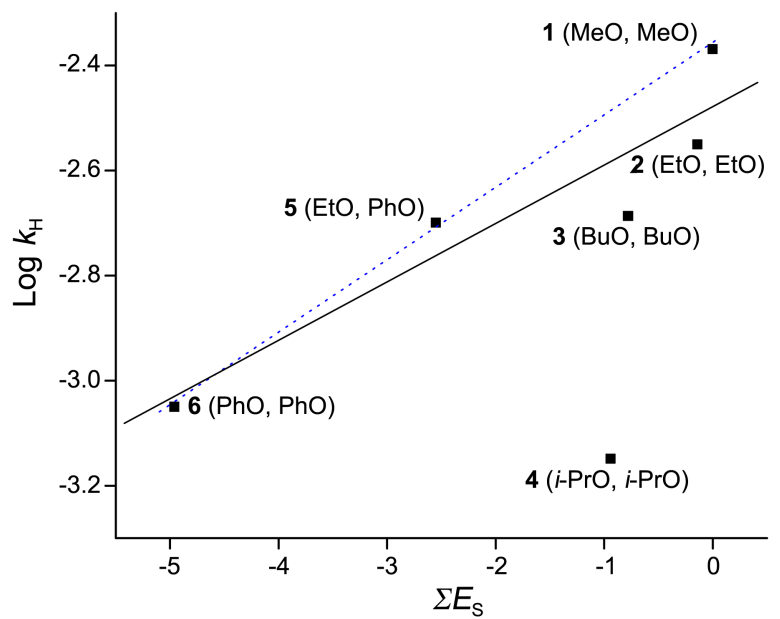

Figure 4. The plot of $\log k_{\mathrm{H}}$ with unsubstituted aniline against $\Sigma E_{\mathrm{S}}$ for the anilinolysis of 1-6 in $\mathrm{MeCN}$ at $55.0^{\circ} \mathrm{C}$. The number of the substrate with the two ligands is displayed next to the corresponding point.

The Taft's eq. (2) can be used to rationalize the steric effect on the reaction rate where $k_{\mathrm{H}}$ is the second-order rate constant, $E_{\mathrm{S}}$ is the Taft's steric constant $\left[E_{\mathrm{S}}(\mathrm{R})=0(\mathrm{Me})\right.$; $-0.07(\mathrm{Et}) ;-0.39(\mathrm{Bu}) ;-0.47(i-\mathrm{Pr}) ;-2.48(\mathrm{Ph})], \Sigma E_{\mathrm{S}}$ is the summation of the steric constants of the two ligands, and $\delta$ is the sensitivity coefficient. ${ }^{11}$

Table 3. Steric Effects of the Two ligands on the Rates of the $\mathrm{P}=\mathrm{O}$ Systems of $\mathbf{I}-\mathbf{V}$ in a Given Solvent ${ }^{a}$

\begin{tabular}{|c|c|c|c|}
\hline No & Reaction system & Solvent & $\delta$ \\
\hline I & $\mathrm{O}(\mathrm{MeO}, \mathrm{MeO}), \mathrm{O}(\mathrm{EtO}, \mathrm{PhO}), \mathrm{O}(\mathrm{PhO}, \mathrm{PhO})+$ anilines & $\mathrm{MeCN}$ & $0.14(\mathrm{r}=0.999)$ \\
\hline $\mathbf{I}^{\prime}$ & $\mathrm{O}(\mathrm{MeO}, \mathrm{MeO}), \mathrm{O}(\mathrm{EtO}, \mathrm{EtO}), \mathrm{O}(\mathrm{EtO}, \mathrm{PhO}), \mathrm{O}(\mathrm{PhO}, \mathrm{PhO})+$ anilines & $\mathrm{MeCN}$ & $0.12(r=0.967)$ \\
\hline $\mathbf{I}^{\prime \prime}$ & $\mathrm{O}(\mathrm{MeO}, \mathrm{MeO}), \mathrm{O}(\mathrm{EtO}, \mathrm{EtO}), \mathrm{O}(\mathrm{BuO}, \mathrm{BuO}), \mathrm{O}(\mathrm{EtO}, \mathrm{PhO}), \mathrm{O}(\mathrm{PhO}, \mathrm{PhO})+$ anilines & $\mathrm{MeCN}$ & $0.11(r=0.930)$ \\
\hline II & $\mathrm{O}(\mathrm{Me}, \mathrm{Me}), \mathrm{O}(\mathrm{Me}, \mathrm{Ph}), \mathrm{O}(\mathrm{Ph}, \mathrm{Ph})+$ anilines & $\mathrm{MeCN}$ & $0.74(\mathrm{r}=0.999)$ \\
\hline II' & $\mathrm{O}(\mathrm{Me}, \mathrm{Me}), \mathrm{O}(\mathrm{Et}, \mathrm{Et}), \mathrm{O}(\mathrm{MePh}), \mathrm{O}(\mathrm{Ph}, \mathrm{Ph})+$ anilines & $\mathrm{MeCN}$ & $0.57(\mathrm{r}=0.895)$ \\
\hline III & $\mathrm{Me}_{2} \mathrm{P}(=\mathrm{O}) \mathrm{OC}_{6} \mathrm{H}_{4}-4-\mathrm{NO}_{2}, \mathrm{MePhP}(=\mathrm{O}) \mathrm{OC}_{6} \mathrm{H}_{4}-4-\mathrm{NO}_{2}, \mathrm{Ph}_{2} \mathrm{P}(=\mathrm{O}) \mathrm{OC}_{6} \mathrm{H}_{4}-4-\mathrm{NO}_{2}+$ anilines & DMSO & $0.02(r=0.954)$ \\
\hline IV & $\mathrm{Me}_{2} \mathrm{P}(=\mathrm{O}) \mathrm{OC}_{6} \mathrm{H}_{4}-4-\mathrm{NO}_{2}, \mathrm{MePhP}(=\mathrm{O}) \mathrm{OC}_{6} \mathrm{H}_{4}-4-\mathrm{NO}_{2}, \mathrm{Ph}_{2} \mathrm{P}(=\mathrm{O}) \mathrm{OC}_{6} \mathrm{H}_{4}-4-\mathrm{NO}_{2}+$ ethanol & $\mathrm{EtOH}$ & $0.48(\mathrm{r}=0.953)$ \\
\hline $\mathbf{V}$ & $\mathrm{Me}_{2} \mathrm{P}(=\mathrm{O}) \mathrm{OC}_{6} \mathrm{H}_{4}-4-\mathrm{NO}_{2}, \mathrm{Ph}_{2} \mathrm{P}(=\mathrm{O}) \mathrm{OC}_{6} \mathrm{H}_{4}-4-\mathrm{NO}_{2}+$ water & water & 0.35 \\
\hline
\end{tabular}

${ }^{a}$ For convenience to express the substrates, $\left(\mathrm{R}_{1} \mathrm{O}\right)\left(\mathrm{R}_{2} \mathrm{O}\right) \mathrm{P}(=\mathrm{O}) \mathrm{Cl}$ and $\mathrm{R}_{1} \mathrm{R}_{2} \mathrm{P}(=\mathrm{O}) \mathrm{Cl}$-types are denoted as $\mathrm{O}\left(\mathrm{R}_{1} \mathrm{O}, \mathrm{R}_{2} \mathrm{O}\right)$ and $\mathrm{O}\left(\mathrm{R}_{1}, \mathrm{R}_{2}\right)$, respectively. 


$$
\log k_{\mathrm{H}}=\delta \Sigma E_{\mathrm{S}}+\mathrm{C}
$$

Figure 4 shows the plot of $\log k_{\mathrm{H}}$ with unsubstituted aniline $\left(\mathrm{C}_{6} \mathrm{H}_{5} \mathrm{NH}_{2}\right)$ against the summation of the Taft's steric constants of the two ligands for the anilinolyses of six $\left(\mathrm{R}_{1} \mathrm{O}\right)\left(\mathrm{R}_{2} \mathrm{O}\right) \mathrm{P}(=\mathrm{O})$ Cl-type chlorophosphates (1-6) in MeCN at $55.0{ }^{\circ} \mathrm{C}$, according to eq. (2). It should be noted that the value of $\Sigma E_{\mathrm{S}}$ is not $E_{\mathrm{S}}\left(\mathrm{R}_{1} \mathrm{O}\right)+E_{\mathrm{S}}\left(\mathrm{R}_{2} \mathrm{O}\right)$ but $E_{\mathrm{S}}\left(\mathrm{R}_{1}\right)+E_{\mathrm{S}}\left(\mathrm{R}_{2}\right)$ because of the lack of data of the Taft's steric constant of $\mathrm{R}_{\mathrm{i}} \mathrm{O}$. The sensitivity coefficients of $\delta$ for five phosphoryl transfer reaction systems (I-V) in a given solvent are summarized in Table 3.

The relative reactivities of each reaction system of $\mathbf{I}-\mathbf{V}$ are predominantly dependent upon the steric effects over the inductive effects of the two ligands. Henceforth, for convenience to express the substrates, $\left(\mathrm{R}_{1} \mathrm{O}\right)\left(\mathrm{R}_{2} \mathrm{O}\right) \mathrm{P}(=\mathrm{O}) \mathrm{Cl}$ and $\mathrm{R}_{1} \mathrm{R}_{2} \mathrm{P}(=\mathrm{O})$ Cl-types are denoted as $\mathrm{O}\left(\mathrm{R}_{1} \mathrm{O}, \mathrm{R}_{2} \mathrm{O}\right)$ and $\mathrm{O}\left(\mathrm{R}_{1}, \mathrm{R}_{2}\right)$, respectively. In the $\mathrm{P}=\mathrm{O}$ system of $\mathbf{I}$ (and $\left.\mathbf{I}^{\prime}, \mathbf{I}^{\prime \prime}\right)$, the obtained values of sensitivity coefficients are $\delta=0.14(\mathrm{r}$ $=0.999)$ with $\mathbf{1}, \mathbf{5}$, and $\mathbf{6}(\mathbf{I}), \delta=0.12(\mathrm{r}=0.967)$ with $\mathbf{1}, \mathbf{2}, \mathbf{5}$, and $\mathbf{6}\left(\mathbf{I}^{\prime}\right)$ and $\delta=0.11(\mathrm{r}=0.930)$ with $\mathbf{1}, \mathbf{2}, \mathbf{3}, \mathbf{5}$, and $\mathbf{6}\left(\mathbf{I}^{\prime \prime}\right)$. These results suggest that the anilinolysis rates of $\mathbf{1}, \mathbf{2}, \mathbf{3}, \mathbf{5}$, and 6 are qualitatively (or semi-quantitatively) controlled by the steric effects over the inductive effects of the two ligands. However, the anilinolysis rate of $\mathbf{4}$ exhibits exceptionally negative deviation from the slope of $\delta=0.11(0.12$ and 0.14). The substrate of $\mathbf{4}$ has not only the greatest magnitude of the positive charge at the reaction center $\mathrm{P}$ atom among six substrates but also smaller size of the two ligands compared to $\mathbf{5}$ and $\mathbf{6}$. This means that the anilinolysis rate of $\mathbf{4}$ (with two $i$-PrO ligands) is exceptionally slow to be rationalized by the normal stereoelectronic effects. In the $\mathrm{P}=\mathrm{O}$ system of $\mathbf{I I}$ (and II'), the anilinolysis rate of $\mathrm{O}(\mathrm{Et}, \mathrm{Et})$ is somewhat slow and that of $\mathrm{O}(\mathrm{cHex}, \mathrm{cHex})^{13}$ is exceptionally too slow to be rationalized by the conventional stereoelectronic effects. ${ }^{11,0}$ All these results might indicate that: (i) the steric effects of ethyl, butyl, $i$-propyl, and cyclo-hexyl ligands are greater than the reference reaction of Taft's eq. or (ii) another additional factor plays an important role to decide the anilinolysis rate. Thus, further systematic studies are essential to clarify the structure and reactivity relationship. Despite the greater size of $\mathrm{R}_{\mathrm{i}} \mathrm{O}$ than that of its corresponding $\mathrm{R}_{\mathrm{i}}$, the steric effects of the two ligands on the anilinolysis rates (reaction systems of $\mathbf{I}-\mathbf{I I}^{\prime}$ ) are smaller in $\mathrm{O}\left(\mathrm{R}_{\mathrm{i}} \mathrm{O}, \mathrm{R}_{\mathrm{j}} \mathrm{O}\right)$-type than in $\mathrm{O}\left(\mathrm{R}_{\mathrm{i}}, \mathrm{R}_{\mathrm{j}}\right)$-type: e.g., $k_{\mathrm{H}}[\mathrm{O}(\mathrm{Me}, \mathrm{Me})] / k_{\mathrm{H}}[\mathrm{O}(\mathrm{Ph}, \mathrm{Ph})]=4,520^{1 \mathrm{~d}, \mathrm{i}}$ while $k_{\mathrm{H}}[\mathrm{O}(\mathrm{MeO}$, $\mathrm{MeO})] / k_{\mathrm{H}}[\mathrm{O}(\mathrm{PhO}, \mathrm{PhO})]=4.8 .^{1 \mathrm{a}, \mathrm{g}}$ This means that the intervening oxygen atom between the reaction center phosphorus atom and $\mathrm{R}_{\mathrm{i}}$ reduces the steric congestion when the nucleophile attacks the reaction center $\mathrm{P}$ atom in the TS. In the $\mathrm{P}=\mathrm{O}$ system of III, the sensitivity coefficient of $\delta$ is considerably small, however, it is evident that the steric effects are the predominant factor to determine the anilinolysis rate over the inductive effects of the two ligands. ${ }^{1 \mathrm{~m}}$ In the $\mathrm{P}=\mathrm{O}$ systems of $\mathbf{I V}^{14}$ and $\mathbf{V},{ }^{15}$ the ethanolysis and hydrolysis rates are also strongly influenced by the steric effects over the inductive effects of the two ligands.
Table 4. Activation Parameters of the Reactions of 1-6 in $\mathrm{MeCN}$ and 9 in DMSO with $\mathrm{C}_{6} \mathrm{H}_{5} \mathrm{NH}_{2}$ at $55.0{ }^{\circ} \mathrm{C}$

\begin{tabular}{ccc}
\hline Substrate & $\Delta H^{\ddagger} / \mathrm{kcal} \mathrm{mol}^{-1}$ & $-\Delta S^{\ddagger} / \mathrm{cal} \mathrm{mol}^{-1} \mathrm{~K}^{-1}$ \\
\hline 1: $(\mathrm{MeO})_{2} \mathrm{P}(=\mathrm{O}) \mathrm{Cl}$ & 6.3 & 50 \\
2: $(\mathrm{EtO})_{2} \mathrm{P}(=\mathrm{O}) \mathrm{Cl}$ & 8.6 & 44 \\
3: $(\mathrm{BuO})_{2} \mathrm{P}(=\mathrm{O}) \mathrm{Cl}^{a}$ & 6.4 & 52 \\
4: $(i-\mathrm{PrO})_{2} \mathrm{P}(=\mathrm{O}) \mathrm{Cl}$ & 7.2 & 51 \\
5: $(\mathrm{EtO})(\mathrm{PhO}) \mathrm{P}=\mathrm{O}) \mathrm{Cl}$ & 6.8 & 51 \\
6: $(\mathrm{PhO})_{2} \mathrm{P}(=\mathrm{O}) \mathrm{Cl}$ & 9.7 & 43 \\
9: $\left(2,6-\mathrm{Me}_{2} \mathrm{C}_{6} \mathrm{H}_{3} \mathrm{O}\right)_{2} \mathrm{P}(=\mathrm{O}) \mathrm{Cl}$ & 13.2 & 29 \\
\hline
\end{tabular}

${ }^{a}$ See ref. 16 .

As seen in Table 3, the sensitivity coefficient value of $\delta$ is strongly dependent upon the reaction system and solvent. It is worthy of note that the steric effects of the two ligands are no longer dominant factor to determine the pyridinolysis rates of both $\mathrm{P}=\mathrm{O}$ and $\mathrm{P}=\mathrm{S}$ systems. ${ }^{2}$ Regarding the steric effects of the two ligands, the horizontal approach of the aniline ring should cause excessive steric hindrance in contrast to a much less steric effects in the vertical approach of the pyridine ring. ${ }^{10,2 a}$

Comparing the activation parameters of the reactions of 1-6 in $\mathrm{MeCN}$ and 9 in DMSO with $\mathrm{C}_{6} \mathrm{H}_{5} \mathrm{NH}_{2}$ at $55.0{ }^{\circ} \mathrm{C}$ in Table 4 , the enthalpies of activation have relatively small values $\left(6-10 \mathrm{kcal} \mathrm{mol}^{-1}\right)$ and the entropies of activation have relatively great negative values $\left(-43\right.$ to $\left.-51 \mathrm{cal} \mathrm{mol}^{-1} \mathrm{~K}^{-1}\right)$ for 1-6, while the enthalpy of activation has relatively great value $\left(13.2 \mathrm{kcal} \mathrm{mol}^{-1}\right)$ and the entropy of activation has relatively small negative value $\left(-29 \mathrm{cal} \mathrm{mol}^{-1} \mathrm{~K}^{-1}\right)$ for 9 . Thus, it seems difficult to suggest the mechanism from the activation parameters of 1-6.

The DKIEs are one of the strong tools to clarify the reaction mechanism. The DKIEs have provided a useful means to determine the TS structures in the nucleophilic substitution reactions, and how the reactants, especially through changes in substituents, alter the TS structures. Incorporation of deuterium in the nucleophile has an advantage in that the $\alpha$-DKIEs reflect only the degree of bond formation. When partial deprotonation of the aniline occurs in a rate-limiting step by hydrogen bonding, the $k_{\mathrm{H}} / k_{\mathrm{D}}$ values are greater than unity, primary normal $\left(k_{\mathrm{H}} / k_{\mathrm{D}}>1.0\right) .{ }^{17}$ The greater the extent of the hydrogen bond, the value of $k_{\mathrm{H}} / k_{\mathrm{D}}$ becomes greater. In contrast, the DKIEs can only be secondary inverse $\left(k_{\mathrm{H}} / k_{\mathrm{D}}<1.0\right)$ in a normal $\mathrm{S}_{\mathrm{N}} 2$ reaction, since the $\mathrm{N}-\mathrm{H}(\mathrm{D})$ vibrational frequencies invariably increase upon going to the TS because of an increase in steric congestion in the bond-making process. ${ }^{18}$ The greater the degree of the steric congestion in the TS, the value of $k_{\mathrm{H}} / k_{\mathrm{D}}$ becomes smaller.

The attacking direction of aniline nucleophile can be semiquantitatively divided into three groups on the basis of the magnitudes of the $k_{\mathrm{H}} / k_{\mathrm{D}}$ values: (i) predominant backside attack TSb (Scheme 2) when $k_{\mathrm{H}} / k_{\mathrm{D}}<1$; (ii) the fraction of the frontside attack involving a hydrogen-bonded fourcenter-type TSf (Scheme 2) is greater than that of backside attack TSb when $1.0<k_{\mathrm{H}} / k_{\mathrm{D}}<1.1$ : (iii) predominant front- 


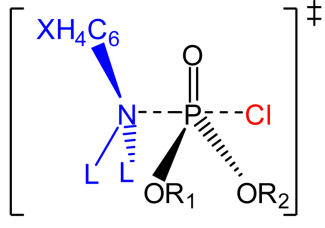

$\mathrm{TSb}$

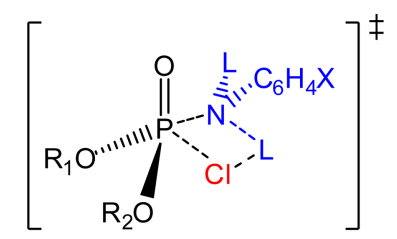

TSf
Scheme 2. Backside attack TSb and frontside attack TSf.

side attack TSf when $k_{\mathrm{H}} / k_{\mathrm{D}}>1.1 .^{19}$

As seen in Table 2 , the DKIEs of $1\left(k_{\mathrm{H}} / k_{\mathrm{D}}=0.80-0.98\right),{ }^{1 \mathrm{~g}} \mathbf{2}$ $\left(k_{\mathrm{H}} / k_{\mathrm{D}}=0.71-0.92\right),{ }^{1 \mathrm{~g}} 4\left(k_{\mathrm{H}} / k_{\mathrm{D}}=0.71-0.92\right),{ }^{1 \mathrm{r}} 6\left(k_{\mathrm{H}} / k_{\mathrm{D}}=0.61-\right.$ $0.87),{ }^{1 \mathrm{a}} 7\left(k_{\mathrm{H}} / k_{\mathrm{D}}=0.64-0.87\right),{ }^{1 \mathrm{~b}} \mathbf{8}\left(k_{\mathrm{H}} / k_{\mathrm{D}}=0.55-0.98\right),{ }^{1 \mathrm{n}}$ and $9\left(k_{\mathrm{H}} / k_{\mathrm{D}}=0.87-0.92\right)^{1 \mathrm{t}}$ are secondary inverse, while those of $5\left(k_{\mathrm{H}} / k_{\mathrm{D}}=1.07-1.28\right)^{1 \mathrm{f}}$ are primary normal. In the present work of 3 , the DKIEs are secondary inverse $\left(k_{\mathrm{H}} / k_{\mathrm{D}}=0.86-\right.$ $0.97)$ with the strongly basic anilines $(\mathrm{X}=4-\mathrm{MeO}, 4-\mathrm{Me}, 3-$ $\mathrm{Me}, \mathrm{H})$, while primary normal $\left(k_{\mathrm{H}} / k_{\mathrm{D}}=1.04-1.10\right)$ with the weakly basic anilines $(\mathrm{X}=3-\mathrm{MeO}, 4-\mathrm{Cl}, 3-\mathrm{Cl})$. The authors accordingly propose the attacking direction of the aniline nucleophile: (i) predominant backside attack TSb for 1, 2, 4, 6, 7, 8, and 9; (ii) predominant frontside attack involving a hydrogen-bonded four-center-type TSf for 5; and (iii) predominant backside attack with the strongly basic anilines and frontside attack with the weakly basic anilines for $\mathbf{3}$.

Focus now shifts to the anilinolysis mechanism of 1-9 on the basis of the CICs and variation trends of the $k_{\mathrm{H}} / k_{\mathrm{D}}$ values with substituent $\mathrm{X}$ in the nucleophiles. The CIC is also one of the strong tools to clarify the reaction mechanism. ${ }^{12}$ The sign of the CIC $\left(\rho_{\mathrm{XY}}\right)$ is negative in a normal $\mathrm{S}_{\mathrm{N}} 2$ reaction (or in a stepwise reaction with a rate-limiting bond formation), and positive in a stepwise reaction with a rate-limiting leaving group expulsion from the intermediate. The magnitude of the CIC is inversely proportional to the distance between $\mathrm{X}$ and $\mathrm{Y}$ through the reaction center; the tighter the TS, the greater the magnitude of the CIC. Thus, the authors proposed that the anilinolyses of $\mathbf{5}, \mathbf{6}$, and $\mathbf{7}$ proceed through a concerted mechanism on the basis of the negative sign of CIC, ${ }^{1 \text { fa, b }}$ while that of $\mathbf{8}$ proceeds through a stepwise mechanism with a rate-limiting leaving group expulsion from the intermediate on the basis of the positive sign of CIC. ${ }^{1 \mathrm{n}}$

The variation trends of the DKIEs with $\mathrm{X}$ of the anilinolyses of 1, 2, 6, and 7 are the same as $\uparrow$, in which the DKIEs are secondary inverse for all the anilines: the weaker the nucleophile, the greater steric hindrance occurs in the TS, the secondary inverse DKIE becomes smaller, and the greater degree of bond formation occurs. Thus, the authors proposed that the anilinolyses of $\mathbf{1}$ and $\mathbf{2}$ proceed through a concerted mechanism on the basis of the variation trends of the DKIEs of $\uparrow$ with $X .^{1 \mathrm{~g}}$ In the case of $\mathbf{8}$ in which the mechanism is a stepwise process with a rate-limiting bond breaking step, ${ }^{\text {1n }}$ the DKIEs are secondary inverse for all the anilines with the variation trend of the DKIEs of $\downarrow$ with X: the stronger the nucleophile, the greater steric hindrance occurs in the TS, the secondary inverse DKIE becomes smaller, and the greater degree of bond formation occurs.
Table 5. Variation Trends of the DKIEs with $\mathrm{X}$ of the Anilinolysis Mechanisms of $\left(\mathrm{R}_{1} \mathrm{O}\right)\left(\mathrm{R}_{2} \mathrm{O}\right) \mathrm{P}(=\mathrm{O})$ Cl-type Chlorophosphates

\begin{tabular}{|c|c|c|c|}
\hline \multicolumn{2}{|c|}{ Mechanism $\backslash$ DKIE } & $k_{\mathrm{H}} / k_{\mathrm{D}}<1$ & $k_{\mathrm{H}} / k_{\mathrm{D}}>1$ \\
\hline \multicolumn{2}{|c|}{ Concerted } & $\uparrow$ & $\downarrow$ \\
\hline \multirow{2}{*}{ Stepwise } & Bond formation & $\uparrow$ & $\downarrow$ \\
\hline & Bond breaking & $\downarrow$ & $\uparrow$ \\
\hline
\end{tabular}

Thus, the proposed mechanism of 9 is a stepwise process with a rate-limiting leaving group expulsion from the intermediate on the basis of the variation trend of the DKIEs of $\downarrow$ with $X^{1 \mathrm{t}}$ In the case of $\mathbf{5}$ in which the mechanism is a concerted $\mathrm{S}_{\mathrm{N}} 2$ process, the DKIEs are primary normal for all the anilines with the variation trend of the DKIEs of $\downarrow$ with $\mathrm{X}$ : a less basic aniline leads to a greater extent of hydrogen bond formation. ${ }^{1 f}$ The variation trends of the DKIEs with substituent $\mathrm{X}$ in the nucleophiles depending on the reaction mechanism of the anilinolysis of the chlorophosphates are summarized in Table 5.

In the case of 4 , the variation trends of the secondary inverse DKIEs, denoted as $\downarrow+\uparrow$, is divided into two parts: $\downarrow$ with the strongly basic anilines $\left[\mathrm{X}=4-\mathrm{MeO}\left(k_{\mathrm{H}} / k_{\mathrm{D}}=0.88\right)<\right.$ 4- $\mathrm{Me}(0.90)<3-\mathrm{Me}(0.92)<\mathrm{H}(0.95 ;$ maximum $)]$ and $\uparrow$ with the weakly basic anilines $\left[\mathrm{X}=4-\mathrm{F}\left(k_{\mathrm{H}} / k_{\mathrm{D}}=0.87\right)>4\right.$ $\mathrm{Cl}(0.77)>3-\mathrm{Cl}(0.71)] .{ }^{1 \mathrm{r}}$ Thus, a stepwise mechanism with a rate-limiting bond breaking for the strongly basic anilines and with a rate-limiting bond formation for the weakly basic anilines is proposed for the anilinolysis of $\mathbf{4}$ on the basis of the variation trend of the DKIEs. In the present work of $\mathbf{3}$, the variation trend of the DKIEs, denoted as $\uparrow+\downarrow$, is divided into two parts: secondary inverse with $\mathrm{X}$ for the strongly basic anilines shows $\uparrow\left[\mathrm{X}=4-\mathrm{MeO}\left(k_{\mathrm{H}} / k_{\mathrm{D}}=0.97\right)>4-\right.$ $\mathrm{Me}(0.94)>3-\mathrm{Me}(0.90)>\mathrm{H}(0.86)]$, and primary normal for the weakly basic anilines shows $\downarrow\left[\mathrm{X}=3-\mathrm{MeO}\left(k_{\mathrm{H}} / k_{\mathrm{D}}=1.04\right)\right.$ $<4-\mathrm{Cl}(1.06)<3-\mathrm{Cl}(1.10)]$. Thus the authors propose a concerted $\mathrm{S}_{\mathrm{N}} 2$ mechanism for both the strongly and weakly basic anilines regardless of the DKIEs, primary normal or secondary inverse, on the variation trends of the DKIEs with $X$. The linear free energy relationship in the present work implies that the attacking direction of the aniline gradually changes from a backside with the strongly basic anilines to a frontside involving a hydrogen-bonded four-center-type TSf with the weakly basic anilines.

\section{Experimental Section}

Materials. Dibutyl chlorophosphate (commercially available) and HPLC grade acetonitrile (water content is less than $0.005 \%$ ) were used for kinetic studies without further purification. Anilines were redistilled or recrystallized before use as previously described. ${ }^{1}$ Deuterated anilines were synthesized by heating anilines and deuterium oxide ( 99.9 atom $\% \mathrm{D}$ ) and one drop of $\mathrm{HCl}$ as catalyst at $85^{\circ} \mathrm{C}$ for $72 \mathrm{hr}$, and after numerous attempts, anilines were deuterated more than $98 \%$, as confirmed by ${ }^{1} \mathrm{H}$ NMR.

Kinetic Procedure. Rates were measured conductometrically in $\mathrm{MeCN}$ at $55.0{ }^{\circ} \mathrm{C}$. The conductivity bridge used in 
this work was a self-made computer automated A/D converter conductivity bridge. Pseudo-first-order rate constants, $k_{\text {obsd, }}$, were measured by curve fitting analysis in origin program with a large excess of anilines, [substrate] $=1 \times 10^{-3}$ $\mathrm{M}$ and [X-aniline $]=(0.1-0.3) \mathrm{M}$. Second-order rate constants, $k_{2}$, were obtained from the slope of a plot of $k_{\text {obsd }} v s$ [X-aniline] with at least five concentrations of anilines. The pseudo-first-order rate constant values $\left(k_{\text {obsd }}\right)$ were the average of at least three runs which were reproducible within $\pm 3 \%$.

Product Analysis. Dibutyl chlorophosphate was reacted with excess aniline for more than 15 half-lives at $55.0^{\circ} \mathrm{C}$ in $\mathrm{MeCN}$. The aniline hydrochloride salt was separated by filtration. Acetonitrile was evaporated under reduced pressure. The product was isolated with ether by a work-up process and dried over anhydrous $\mathrm{MgSO}_{4}$. After filtration the product was isolated by evaporating the solvent under reduced pressure. The analytical and spectroscopic data of the product gave the following results:

$(\mathbf{B u O})_{2} \mathbf{P}(=\mathbf{O}) \mathbf{N H C}_{6} \mathbf{H}_{5}$. Orange liquid; ${ }^{1} \mathrm{H}$ NMR (400 $\left.\mathrm{MHz}, \mathrm{CDCl}_{3}\right) \delta 0.85-0.89\left(\mathrm{~m}, 6 \mathrm{H}, 2 \mathrm{CH}_{3}, \mathrm{Bu}\right), 1.33-1.39(\mathrm{~m}$, $\left.4 \mathrm{H}, 2 \mathrm{CH}_{2}, \mathrm{Bu}\right), 1.60-1.65\left(\mathrm{~m}, 4 \mathrm{H}, 2 \mathrm{CH}_{2}, \mathrm{Bu}\right), 3.98-4.02$ (m, 2H, $\left.\mathrm{CH}_{2}, \mathrm{Bu}\right), 4.08-4.12\left(\mathrm{~m}, 2 \mathrm{H}, \mathrm{CH}_{2}, \mathrm{Bu}\right), 5.04(\mathrm{~s}, 1 \mathrm{H}$, $\mathrm{NH}), 6.95-7.00(\mathrm{t}, J=7.6 \mathrm{~Hz}, 3 \mathrm{H}$, phenyl), 7.21-7.23 (d, $J=$ $7.6 \mathrm{~Hz}, 2 \mathrm{H}$, phenyl); ${ }^{13} \mathrm{C} \mathrm{NMR}\left(100 \mathrm{MHz}, \mathrm{CDCl}_{3}\right) \delta 13.49$ $\left(\mathrm{CH}_{3}, \mathrm{Bu}\right), 18.68\left(\mathrm{CH}_{2}, \mathrm{Bu}\right), 32.12,32.19\left(\mathrm{CH}_{2}, \mathrm{Bu}\right), 66.54$, $66.59\left(\mathrm{CH}_{2}, \mathrm{Bu}\right), 117.26,117.34,121.63,129.22,139.52$ $\left(\mathrm{C}=\mathrm{C}\right.$, aromatic); ${ }^{31} \mathrm{P} \mathrm{NMR}\left(162 \mathrm{MHz}, \mathrm{CDCl}_{3}\right) \delta 7.94(\mathrm{~s}, 1 \mathrm{P}$, $\mathrm{P}=\mathrm{O})$; $\mathrm{MS}(\mathrm{EI}) m / z 285\left(\mathrm{M}^{+}\right)$.

Acknowledgments. This work was supported by Inha University Research Grant.

\section{References and Notes}

1. (a) Guha, A. K.; Lee, H. W.; Lee, I. J. Chem. Soc., Perkin Trans. 2 1999, 765. (b) Lee, H. W.; Guha, A. K.; Lee, I. Int. J. Chem. Kinet. 2002, 34, 632. (c) Hoque, M. E. U.; Dey, S.; Guha, A. K.; Kim, C. K.; Lee, B. S.; Lee, H. W. J. Org. Chem. 2007, 72, 5493. (d) Hoque, M. E. U.; Lee, H. W. Bull. Korean Chem. Soc. 2007, 28, 936. (e) Dey, N. K.; Han, I. S.; Lee, H. W. Bull. Korean Chem. Soc. 2007, 28, 2003. (f) Hoque, M. E. U.; Dey, N. K.; Kim, C. K.; Lee, B. S.; Lee, H. W. Org. Biomol. Chem. 2007, 5, 3944. (g) Dey, N. K.; Hoque, M. E. U.; Kim, C. K.; Lee, B. S.; Lee, H. W. J. Phys. Org. Chem. 2008, 21, 544. (h) Lumbiny, B. J.; Lee, H. W. Bull. Korean Chem. Soc. 2008, 29, 2065. (i) Dey, N. K.; Hoque, M. E. U.; Kim, C. K.; Lee, B. S.; Lee, H. W. J. Phys. Org. Chem. 2009, 22, 425. (j) Dey, N. K.; Kim, C. K.; Lee, H. W. Bull. Korean Chem. Soc. 2009, 30, 975. (k) Hoque, M. E. U.; Guha, A. K.; Kim, C. K.; Lee, B. S.; Lee, H. W. Org. Biomol. Chem. 2009, 7, 2919. (1) Dey, N. K.; Lee, H. W. Bull. Korean Chem. Soc. 2010, 31, 1403. (m) Dey, N. K.; Kim, C. K.; Lee, H. W. Org. Biomol. Chem. 2011, 9, 717. (n) Barai, H. R.; Lee, H. W. Bull. Korean Chem. Soc. 2011, 32, 1939. (o) Hoque, M. E. U.; Lee, H. W. Bull. Korean Chem. Soc. 2011, 32, 1997. (p) Hoque, M. E. U.; Lee, H. W. Bull. Korean Chem. Soc. 2011, 32, 2306. (q) Adhikary, K. K.; Lumbiny, B. J.; Dey, S.; Lee, H. W. Bull. Korean Chem. Soc. 2011, 32, 2628. (r) Hoque, M. E. U.; Lee, H. W. Bull. Korean Chem. Soc. 2011, 32, 3245. (s) Barai, H. R.; Lee, H. W. Bull. Korean Chem. Soc. 2011, 32, 3355. (t) Barai, H. R.; Lee, H. W. Bull. Korean Chem. Soc. 2011, 32, 3783. (u) Hoque, M. E. U.;
Lee, H. W. Bull. Korean Chem. Soc. 2011, 32, 3880.

2. (a) Guha, A. K.; Lee, H. W.; Lee, I. J. Org. Chem. 2000, 65, 12. (b) Lee, H. W.; Guha, A. K.; Kim, C. K.; Lee, I. J. Org. Chem. 2002, 67, 2215. (c) Adhikary, K. K.; Lee, H. W.; Lee, I. Bull. Korean Chem. Soc. 2003, 24, 1135. (d) Hoque, M. E. U.; Dey, N. K.; Guha, A. K.; Kim, C. K.; Lee, B. S.; Lee, H. W. Bull. Korean Chem. Soc. 2007, 28, 1797. (e) Adhikary, K. K.; Lumbiny, B. J.; Kim, C. K.; Lee, H. W. Bull. Korean Chem. Soc. 2008, 29, 851. (f) Lumbiny, B. J.; Adhikary, K. K.; Lee, B. S.; Lee, H. W. Bull. Korean Chem. Soc. 2008, 29, 1769. (g) Dey, N. K.; Hoque, M. E. U.; Kim, C. K.; Lee, H. W. J. Phys. Org. Chem. 2010, 23, 1022. (h) Dey, N. K.; Adhikary, K. K.; Kim, C. K.; Lee, H. W. Bull. Korean Chem. Soc. 2010, 31, 3856. (i) Dey, N. K.; Kim, C. K.; Lee, H. W. Bull. Korean Chem. Soc. 2011, 32, 709. (j) Hoque, M. E. U.; Dey, S.; Kim, C. K.; Lee, H. W. Bull. Korean Chem. Soc. 2011, 32, 1138. (k) Guha, A. K.; Hoque, M. E. U.; Lee, H. W. Bull. Korean Chem. Soc. 2011, 32, 1375. (1) Guha, A. K.; Kim, C. K.; Lee, H. W. J. Phys. Org. Chem. 2011, 24, 474. (m) Adhikary, K. K.; Lee, H. W. Bull. Korean Chem. Soc. 2011, 32, 1945. (n) Hoque, M. E. U.; Lee, H. W. Bull. Korean Chem. Soc. 2011, 32, 2109. (o) Barai, H. R.; Lee, H. W. Bull. Korean Chem. Soc. 2011, 32, 2339. (p) Hoque, M. E. U.; Lee, H. W. Bull. Korean Chem. Soc. 2011, 32, 2805. (q) Hoque, M. E. U.; Lee, H. W. Bull. Korean Chem. Soc. 2011, 32, 3505. (r) Adhikary, K. K.; Lumbiny, B. J.; Lee, H. W. Bull. Korean Chem. Soc. 2011, 32, 3743. (s) Adhikary, K. K.; Lumbiny, B. J.; Lee, H. W. Bull. Korean Chem. Soc. 2011, 32, 3947.

3. (a) Adhikary, K. K.; Lee, H. W. Bull. Korean Chem. Soc. 2011, 32 , 1625. (b) Adhikary, K. K.; Lee, H. W. Bull. Korean Chem. Soc. 2011, 32, 3587.

4. (a) Lee, I.; Kim, C. K.; Li, H. G.; Sohn, C. K.; Kim, C. K.; Lee, H. W.; Lee, B. S. J. Am. Chem. Soc. 2000, 122, 11162. (b) Han, I. S.; Kim, C. K.; Lee, H. W. Bull. Korean Chem. Soc. 2011, 32, 889.

5. Hehre, W. J.; Random, L.; Schleyer, P. V. R.; Pople, J. A. Ab Initio Molecular Orbital Theory; Wiley: New York, 1986; Chapter 4.

6. (a) Ritchie, C. D. In Solute-Solvent Interactions; Coetzee, J. F., Ritchie, C. D., Eds.; Marcel Dekker: New York, 1969; Chapter 4. (b) Coetzee, J. F. Prog. Phys. Org. Chem. 1967, 4, 54. (c) Spillane, W. J.; Hogan, G.; McGrath, P.; King, J.; Brack, C. J. Chem. Soc., Perkin Trans. 2 1996, 2099. (d) Oh, H. K.; Woo, S. Y.; Shin, C. H.; Park, Y. S.; Lee, I. J. Org. Chem. 1997, 62, 5780.

7. (a) Perrin, C. I.; Engler, R. E. J. Phys. Chem. 1991, 95, 8431. (b) Perrin, C. I.; Ohta, B. K.; Kuperman, J. J. Am. Chem. Soc. 2003, 125, 15008. (c) Perrin, C. I.; Ohta, B. K.; Kuperman, J.; Liberman, J.; Erdelyi, M. J. Am. Chem. Soc. 2005, 127, 9641.

8. Hansch, C.; Leo, A.; Taft, R. W. Chem. Rev. 1991, 91, 165.

9. Streitwieser, A., Jr.; Heathcock, C. H.; Kosower, E. M. Introduction to Organic Chemistry, 4th ed.; Macmillan: New York, 1992; p 735.

10. Crumpler, T. B.; Yoh, J. H. Chemical Computations and Errors; John Wiley: New York, 1940; p 178.

11. (a) Taft, R. W. Steric Effect in Organic Chemistry; Newman, M. S., Ed.; Wiley: New York, 1956; Chapter 3. (b) Exner, O. Correlation Analysis in Chemistry: Recent Advances; Chapman, N. B., Shorter, J., Eds.; Plenum Press: New York, 1978; p 439.

12. (a) Lee, I. Chem. Soc. Rev. 1990, 19, 317. (b) Lee, I. Adv. Phys. Org. Chem. 1992, 27, 57. (c) Lee, I.; Lee, H. W. Collect. Czech. Chem. Commun. 1999, 64, 1529.

13. The anilinolysis rate of dicyclohexyl phosphinic chloride is exceptionally slow and shows great negative deviation from the Taft plot. See ref. 10.

14. (a) Dunn, E. J.; Buncel, E. Can. J. Chem. 1989, 67, 1440. (b) Dunn, E. J.; Moir, R. Y.; Buncel, E.; Purdon, J. G.; Bannard, R. A. B. Can. J. Chem. 1990, 68, 1837. (c) Buncel, E.; Albright, K. G.; Onyido, I. Org. Biomol. Chem. 2004, 2, 601. (d) Onyido, I.; Albright, K.; Buncel, E. Org. Biomol. Chem. 2005, 3, 1468.

15. (a) Williams, A.; Naylor, R. A. J. Chem. Soc. B 1971, 1967. (b) Douglas K. T.; Williams, A. J. Chem. Soc., Perkin Trans 2 1976, 
515.

16. The second-order rate constants of the anilinolysis of $\mathbf{3}$ with unsubstituted anline $\left(\mathrm{C}_{6} \mathrm{H}_{5} \mathrm{NH}_{2}\right)$ in $\mathrm{MeCN}$ are measured as follows: $k_{\mathrm{H}}=1.44 \pm 0.01\left(45.0^{\circ} \mathrm{C}\right), 2.06 \pm 0.01\left(55.0^{\circ} \mathrm{C}\right)$, and 2.78 $\pm 0.01 \times 10^{-3} \mathrm{M}^{-1} \mathrm{~s}^{-1}\left(65.0^{\circ} \mathrm{C}\right)$. The Erying plot of $\log \left(k_{\mathrm{H}} / T\right) v \mathrm{~s}$ $1 / T$ shows correlation coefficient of $\mathrm{r}=0.999$. Enthalpy of activation of $\Delta H^{\ddagger}=6.4 \pm 0.2 \mathrm{kcal} \mathrm{mol}^{-1}$ and entropy of activation of $\Delta S^{ \pm}=-52 \pm 1 \mathrm{cal} \mathrm{mol}^{-1} \mathrm{~K}^{-1}$ are obtained for the reaction of $\mathbf{3}$ with aniline $\left(\mathrm{C}_{6} \mathrm{H}_{5} \mathrm{NH}_{2}\right)$ in $\mathrm{MeCN}$ at $55.0{ }^{\circ} \mathrm{C}$.

17. (a) Lee, I.; Koh, H. J.; Lee, B. S.; Lee, H. W. J. Chem. Soc., Chem. Commun. 1990, 335. (b) Lee, I. Chem. Soc. Rev. 1995, 24, 223. (c)
Marlier, J. F. Acc. Chem. Res. 2001, 34, 283. (d) Westaway, K. C. Adv. Phys. Org. Chem. 2006, 41, 217. (e) Villano, S. M.; Kato, S.; Bierbaum, V. M. J. Am. Chem. Soc. 2006, 128, 736. (f) Gronert, S.; Fajin, A. E.; Wong, L. J. Am. Chem. Soc. 2007, 129, 5330.

18. (a) Poirier, R. A.; Youliang, W.; Westaway, K. C. J. Am. Chem. Soc. 1994, 116, 2526. (b) Yamata, H.; Ando, T.; Nagase, S.; Hanamusa, M.; Morokuma, K. J. Org. Chem. 1984, 49, 631. (c) Xhao, X. G.; Tucker, S. C.; Truhlar, D. G. J. Am. Chem. Soc. 1991, $113,826$.

19. This lab has cumulated a lot of data of DKIEs for the anilinolyses of various kinds of substrates in $\mathrm{MeCN}$ and DMSO. 